\title{
An Attenuated Strain of Cucumber Green Mottle Mosaic Virus as a Biological Control Agent against Pathogenic Viral Strains
}

\author{
Anna A. Slavokhotova*, Ekaterina A. Istomina, Emma N. Andreeva, Tatyana V. Korostyleva, \\ Vitalij A. Pukhalskij, Alexander N. Shijan, Tatyana I. Odintsova \\ Vavilov Institute of General Genetics, Russian Academy of Sciences, Moscow, Russia \\ Email: *annslav82@gmail.com
}

Received 29 January 2016; accepted 27 March 2016; published 30 March 2016

Copyright @ 2016 by authors and Scientific Research Publishing Inc.

This work is licensed under the Creative Commons Attribution International License (CC BY).

http://creativecommons.org/licenses/by/4.0/

(c) (i) Open Access

\begin{abstract}
Cucumber green mottle mosaic virus (CGMMV), a member of the Tobamovirus genus, causes a severe disease of cucurbits. In the Moscow region of Russian Federation, the incidence of infection on cucumber plants in greenhouses is high; however, the virus is poorly studied. In this work, the full-length genomes of two pathogenic MC-1 and MC-2 strains of CGMMV isolated from cucumber plants grown in greenhouses in the Moscow region and the attenuated VIROG-43M strain were sequenced. Comparison of VIROG-43M nucleotide sequence with those of the pathogenic strains revealed three missense mutations. Their role in attenuation is discussed. For the first time, in a number of trials conducted under laboratory conditions and in commercial greenhouses, the efficiency of the attenuated VIROG-43M strain as a biocontrol agent for cucumber plant protection resulting in significant yield gain was demonstrated. Phylogenetic analysis with 83 full-length CGMMV coat protein genes isolated in 16 different countries showed that Russian strains are related to isolates from Spain, Greece, USA and Israel.
\end{abstract}

\section{Keywords}

Cucumber Green Mottle Mosaic Virus, Tobamovirus, Attenuated Virus Strain, Cross-Protection, Biological Control

\section{Introduction}

During their lifetime plants have to counteract with various pathogens including viruses as one of the most

${ }^{*}$ Corresponding author.

How to cite this paper: Slavokhotova, A.A., Istomina, E.A., Andreeva, E.N., Korostyleva, T.V., Pukhalskij, V.A., Shijan, A.N. and Odintsova, T.I. (2016) An Attenuated Strain of Cucumber Green Mottle Mosaic Virus as a Biological Control Agent against Pathogenic Viral Strains. American Journal of Plant Sciences, 7, 724-732. http://dx.doi.org/10.4236/ajps.2016.75066 
common disease agents. Many viruses are able to systemically infect their hosts due to specific interactions between viral genome/proteins and the host proteins [1]. In turn, plants have developed induced mechanisms to inhibit virus replication and movement which finally prevents disease development. Induced resistance can also be activated by the so-called biocontrol or attenuated viral strains that are able to infect plants, but do not cause visible disease symptoms. In this case, the plant is already "prepared" for severe virus invasion due to specific defense mechanisms including RNA silencing that involves quick degradation of the RNA of the pathogenic strain [2]. Obviously, if resistant varieties are absent or unavailable, the development of novel biocontrol viral strains may be an effective measure to control viral diseases taking into account that chemical protection against viruses is usually inefficient.

Cucumber green mottle mosaic virus (CGMMV) is a member of the Tobamovirus genus. It causes one of the most common diseases of cucurbits, including cucumber, pumpkin, watermelon, melon, squash, gourds, etc. CGMMV forms rod-shaped particles $300 \times 18 \mathrm{~nm}$ in size and contains a single-strand, positive-sense, $\sim 6-\mathrm{kb}$ RNA [3]. The virus was originally described by Ainsworth in the United Kingdom in 1935 [4]. Later, CGMMV was identified in other European countries, such as Greece [5], France [6], and Russian Federation [7]. CGMMV is also widespread in Asia, including India [8], Japan [3], China [9], Korea [10] and Pakistan [11]. Infected plants are characterized by stunted growth, mottling and mosaic on leaves, fruit mottling and distortion. Note that CGMMV symptoms may be difficult to recognize on young seedlings as well as on fruits that can, however, be internally discolored or necrotic. Like all members of the Tobamovirus genus, CGMMV might be preserved in greenhouses, equipment surfaces, and tools for a long time. It can be easily transmitted by seeds, sap or mechanical transfer. Outbreaks of the disease usually occur in greenhouses; however, the virus can also cause substantial yield losses in the field [12]. It should be noted that at present, only a limited number of cucumber varieties resistant to CGMMV are commercially available [12]. For other cucurbits, no resistant varieties have been produced so far. Hence, the development of biocontrol CGMMV strains with high level of crossprotection may represent an effective control measure to protect plants against pathogenic strains.

In the Tobamovirus genus, several attenuated viral strains used as biocontrol agents have been reported: L11A [13], ToMV K [14], and V-69 [15] strains of tomato mosaic virus (ToMV) for tomato plant protection; Tpa18ch, Pa18, C-1421, TPO-2-19 [16] strains against severe isolates of pepper mild mottle mosaic virus (PMMoV), and SH33b strain [17] of CGMMV for muskmelon protection. However, mild CGMMV strains used for cucumber plant protection have not been described so far. In this study, we for the first time describe the attenuated VIROG-43M CGMMV strain that can be used as a biocontrol agent for cucumber protection. We determined the full-length nucleotide sequences of this attenuated strain together with two pathogenic strains isolated from greenhouse-grown cucumber plants in Moscow region. Comparison of the attenuated and pathogenic viral genomes allowed us to detect mutations that led to attenuation in the CGMMV biocontrol strain. In addition, analyzing NCBI GenBank database, we retrieved all available CGMMV genome sequences and performed phylogenetic analysis.

\section{Materials and Methods}

\subsection{Isolation of CGMMV Strains}

Pathogenic CGMMV strains MC-1 and MC-2 were isolated from leaves of cucumber plants during the outbreak of the infection in greenhouses in the Moscow region. The pathogenic CGMMV MC-1 strain produced green mosaic and mottling on cucumber leaves, while the pathogenic strain CGMMV MC-2 in addition to green mosaic and mottling, caused distortion and blistering.

The attenuated CGMMV strain VIROG-43M was obtained after a number of passages of the initial VIROG43 isolate; it represents a more stable analogue of the VIROG-43 strain. VIROG-43 was obtained from the pathogenic CGMMV strain by chemical mutagenesis using nitrous acid as a mutagen followed by selection of attenuated strains. The attenuated VIROG-43M strain was selected by a number of passages of the diluted virus VIROG-43 on plants with local necrotic (Chenopodium amaranticolor) and systemic (Cucumis sativus) reaction to infection. The presence of the attenuated virus in symptomless plants was controlled by DAS-ELISA. Finally, the virus was isolated from cucumber leaves and propagated on the Kurazh F1 variety (Gavrish, Russian Federation). Plants were inoculated with viral particles and grown for 3 weeks in a greenhouse under controlled temperature conditions $\left(25^{\circ} \mathrm{C}\right.$ day $/ 18^{\circ} \mathrm{C}$ night). Viral particles were isolated and purified from infected cucumber leaves by stepwise precipitation with ammonium sulfate [7]. 


\subsection{Sequencing of CGMMV Strains}

Viral RNA was isolated by RNA adsorption on silica gel in the presence of guanidine thiocyanate (GTC) [7]. An ammonium sulfate precipitate of viral particles was dissolved in $2.5 \mathrm{M}$ GTC solution, containing $24 \%$ ethanol. High-molecular-weight RNA was adsorbed on glass fiber filters (GF/F, Whatman) and eluted with RNase-free water. The first cDNA strand was synthesized with RevertAid first strand cDNA synthesis kit (Fermentas, Lithuania) and random hexamer primers following the manufacturer's instructions. The second strand was synthesized, and the fragments were amplified using Taq DNA polymerase and specific primers. To design primers, we preliminarily analyzed nucleotide sequences of CGMMV isolates from the NCBI GenBank. Viral genomic RNA was sequenced at least two times in both directions from overlapping PCR fragments. If any variation in the primary structure of the studied strains occurred, the regions were sequenced more than three times. Amplified fragments were eluted from agarose gel with a Diatom DNA elution kit (Laboratoriya IzoGen, Russia) and sequenced using an ABI PRISM BigDye Terminator v. 3.1 kit. The reaction products were analyzed on an ABI PRISM 3100-Avant automated DNA sequencer. The sequence data for MC-1, MC-2 and VIROG-43M are available under NCBI GenBank accession numbers FJ848666, GQ495274, and GQ495275, respectively.

\subsection{Evaluation of Phenotypic Stability, Interfering Capability and Cross-Protection Efficiency}

The phenotypic stability of the VIROG-43M strain was assayed under laboratory greenhouse conditions. The experiment was repeated three times. In each replication, 33 cucumber plants were inoculated with the pathogenic MC-1 strain and 66 plants with the attenuated VIROG-43M. $0.5 \mu \mathrm{g} / \mathrm{ml}$ of each viral strain was used for inoculation. After two weeks, one half of plants initially inoculated with VIROG-43M were challenged with the pathogenic MC-1 strain. The number of symptomless plants was determined 1.0, 1.5, 2.0 and 2.5 months after first inoculation.

The degree of cross-protection was measured on the Kurazh F1 variety (Gavrish, Russian Federation) of cucumber plants grown in commercial greenhouses. For this experiment, stock solution of the attenuated VIROG43M strain was diluted with water, supplied with carborundum and sprayed on 10 - 12-day-old cucumber seedlings at 1 to 2 fully-expanded-leaf stage. One hectare of inoculated with the VIROG-43M strain and one hectare of non-inoculated control cucumber plants were analyzed throughout 3 months of vegetation during summer and winter crop rotations. The same trial was conducted in commercial greenhouses located in Leningrad, Krasnodar and Moscow regions with three other cucumber varieties: Tristan F1 (Enza Zaden, Holland), Rais F1 (Gavrish, Russia), and Mirabelle F1 (Seminis, Holland). The results are given in the corresponding section and Table 1 and Table 2.

\subsection{DAS-ELISA}

Cucumber plants of the Kurazh F1 variety (Gavrish, Russian Federation) were grown in laboratory greenhouse under controlled temperature and light conditions $\left(25^{\circ} \mathrm{C}\right.$ day $/ 18^{\circ} \mathrm{C}$ night). When plants reached the stage of three fully expanded leaves, two bottom leaves were inoculated with $0.5 \mu \mathrm{g} / \mathrm{ml}$ of each viral strain. On the $3^{\text {rd }}, 7^{\text {th }}, 10^{\text {th }}$ and $14^{\text {th }}$ days post inoculation (d.p.i.), plant leaf discs were sampled and subjected to DAS-ELISA. For each sample (each CGMMV strain), ten plants were grown and inoculated with the corresponding strain. On the $3^{\text {rd }}$ d.p.i., samples for DAS-ELISA were taken from six similarly developed plants. At one time point, two upper non-inoculated leaves were analyzed; from each leaf one leaf disc was taken. The experiment was repeated three times. ADGEN Identikit CGMMV (Neogen, Scotland, UK) was used for DAS-ELISA according to the

Table 1. Phenotypic stability and interfering capability of the attenuated VIROG-43M stain.

\begin{tabular}{ccccc}
\hline & \multicolumn{4}{c}{ Number of symptomless plants, \% } \\
\cline { 2 - 5 } Treatment & $\begin{array}{c}\text { 1.5 months post } \\
\text { inoculation }\end{array}$ & $\begin{array}{c}2.0 \text { months post } \\
\text { inoculation }\end{array}$ & $\begin{array}{c}2.5 \text { months post } \\
\text { inoculation }\end{array}$ & $\begin{array}{c}3.0 \text { months } \\
\text { post inoculation }\end{array}$ \\
\hline VIROG-43M & 100.0 & 100.0 & 98 & 98 \\
VIROG-43M + MC-1 & 98.0 & 95.0 & 93.0 & 85.0 \\
MC-1 & 0.0 & 0.0 & 0.0 & 0.0 \\
\hline
\end{tabular}


Table 2. Suppression of CGMMV symptoms in cucumber plants inoculated with VIROG-43M.

\begin{tabular}{|c|c|c|c|c|c|}
\hline \multirow{2}{*}{$\begin{array}{c}\text { Cucumber hybrid name, } \\
\text { location of commercial } \\
\text { greenhouse }\end{array}$} & \multirow[b]{2}{*}{ Rotation } & \multirow[b]{2}{*}{ Sample } & \multicolumn{3}{|c|}{ Number of plants with mosaic symptoms, \% } \\
\hline & & & $\begin{array}{l}1.0 \text { months } \\
\text { post inoculation }\end{array}$ & $\begin{array}{c}2.0 \text { months } \\
\text { post inoculation }\end{array}$ & $\begin{array}{l}3.0 \text { months } \\
\text { post inoculatior }\end{array}$ \\
\hline \multirow{4}{*}{$\begin{array}{l}\text { Kurazh F1 (Gavrish, } \\
\text { Russia), Moscow region }\end{array}$} & \multirow{2}{*}{ Winter } & VIROG-43M & 0.0 & 1.0 & 1.5 \\
\hline & & Control & 2.0 & 7.5 & 15.0 \\
\hline & \multirow{2}{*}{ Summer } & VIROG-43M & 0.1 & 2.0 & 3.2 \\
\hline & & Control & 2.0 & 12.2 & 34.1 \\
\hline \multirow{2}{*}{$\begin{array}{c}\text { Tristan F1 } \\
\text { (Enza Zaden, Holland), } \\
\text { Leningrad region }\end{array}$} & \multirow{2}{*}{ Winter } & VIROG-43M & $\mathrm{n} / \mathrm{a}$ & $\mathrm{n} / \mathrm{a}$ & 0.5 \\
\hline & & Control & $\mathrm{n} / \mathrm{a}$ & $\mathrm{n} / \mathrm{a}$ & 15.0 \\
\hline \multirow{2}{*}{$\begin{array}{c}\text { Mirabelle F1 } \\
\text { (Seminis, Holland), } \\
\text { Moscow region }\end{array}$} & \multirow{2}{*}{ Winter } & VIROG-43M & $\mathrm{n} / \mathrm{a}$ & $\mathrm{n} / \mathrm{a}$ & 1.5 \\
\hline & & Control & $\mathrm{n} / \mathrm{a}$ & $\mathrm{n} / \mathrm{a}$ & 13.0 \\
\hline \multirow{2}{*}{$\begin{array}{c}\text { Rais F1 (Gavrish, Russia), } \\
\text { Krasnodar region }\end{array}$} & \multirow{2}{*}{ Summer } & VIROG-43M & $\mathrm{n} / \mathrm{a}$ & $\mathrm{n} / \mathrm{a}$ & 3.0 \\
\hline & & Control & $\mathrm{n} / \mathrm{a}$ & $\mathrm{n} / \mathrm{a}$ & 19.0 \\
\hline
\end{tabular}

n/a, not available.

manufacturer's manual. Reactions were read on an MR-96A Microplate Reader (Mindray, China) at $405 \mathrm{~nm}$. For negative control, leaf discs from healthy plants were sampled at each designated time point. Systemically infected with a pathogenic strain and homogenized cucumber leaves supplied by ADGEN were used as positive control.

\subsection{Phylogenetic Analysis of CGMMV Strains}

The phylogenetic tree was built with MEGA6 software [18] on the base of CLUSTAL W alignment of CP nucleotide sequences. The evolutionary history was inferred by the Maximum Likelihood method based on the Tamura-Nei model [19]. Initial tree for the heuristic search was obtained by applying the Neighbor-Joining method to a matrix of pairwise distances estimated using the Maximum Composite Likelihood (MCL) approach. The tree was drawn to scale, with branch lengths measured in the number of substitutions per site. All positions with less than $95 \%$ site coverage were eliminated. That was, fewer than $5 \%$ alignment gaps, missing data, and ambiguous bases were allowed at any position. There were a total of 320 positions in the final dataset.

\section{Results}

\subsection{VIROG-43M, an Attenuated CGMMV Strain for Cucumber Protection}

The procedure for VIROG-43M isolation was described in Material and Methods. The efficiency of the strain as a biocontrol agent was tested on the Kurazh F1 cucumber variety (Gavrish, Russian Federation) in laboratory and commercial greenhouses. Experiments in laboratory greenhouse allowed us to determine phenotypic stability of the VIROG-43M strain, its interfering capability against pathogenic strains, and cross-protection level. We discovered that VIROG-43M exhibited high phenotypic stability since $100 \%$ of cucumber plants inoculated with this attenuated strain showed no visible symptoms throughout two months of observation (Table 1). However, by the $3^{\text {rd }}$ month of vegetation, the number of symptomless plants decreased to $98 \%$, most likely due to mixed infection in $2 \%$ of plants. VIROG-43M also exhibited significant interfering capability, since throughout two months of vegetation, 95\% of cucumber plants inoculated initially with VIROG-43M showed no disease symptoms. By the end of vegetation, the number of symptomless plants reduced, but still was rather high (85\%) in comparison with $0 \%$ of symptomless plants inoculated initially with the pathogenic MC- 1 strain (Table 1 ).

VIROG-43M was also tested in a number of commercial greenhouses on different cucumber varieties. The level of cross-protection was extensively studied on the Kurazh F1 variety (Gavrish, Russia) in a commercial greenhouse located in the Moscow region during summer and winter rotations. The results are shown in Table 2. It is clearly seen from this table that at the end of vegetation in winter rotation only $1.5 \%$ of plants treated with VIROG-43M exhibited mosaic symptoms, while in control plants, this number increased to $15 \%$. In summer 
rotation, the observed indicators increased to 3.2\% for inoculated plants and to $34 \%$ for non-inoculated ones. We also tested other cucumber varieties grown in commercial greenhouses located in diverse regions of Russia (Table 2). We found that by the end of winter rotation, Tristan F1 (Enza Zaden, Holland) and Marabelle F1 (Seminis, Holland) varieties treated with VIROG-43M exhibited mosaic symptoms only in $0.5 \%$ and $1.5 \%$ cases, in contrast to $15 \%$ and $13 \%$ in untreated plants. The Rais F1 variety (Gavrish, Russia) treated with VIROG-43M during summer rotation showed mosaic symptoms in 3.0\% cases, in contrast to 19\% in untreated plants. It should be also noted that using VIROG-43M during winter rotation, yield gain reached 19.8\% on Kurazh F1 (Gavrish, Russia) and 16.5\% on Mirabelle F1 (Seminis, Holland) varieties in comparison to untreated cucumber plants. The obtained results show that VIROG-43M can be applied in greenhouses for cucumber plant protection for two main reasons: this attenuated strain is phenotypically stable and shows high level of cross-protection against pathogenic strains resulting in significant yield gain.

\subsection{Full-Length Genomic Nucleotide Sequences of Pathogenic MC-1 and MC-2 and Attenuated VIROG-43M Strains}

The RNA genomes of MC-1, MC-2, and VIROG-43M CGMMV strains consist of 6422 nucleotides and have the overall structure similar to other tobamoviruses: the first and the second ORFs encode the short replicase (129-kDa) and the long replicase (186-kDa) proteins; the third and the fourth ORFs encode the 29-kDa movement protein (MP) and the 17.4-kDa CP, respectively (Figure 1).

Comparison of the genomes of MC-1 and MC-2 pathogenic strains showed that they differed in 8 nucleotides in the replicase gene and one mismatch in the MP gene. Only the C-2152 - T-2152 mismatch led to amino acid substitution P-698 $\rightarrow \mathrm{L}$ in MC-2 strain in comparison to MC-1 strain (Figure 1). Comparison of the genomes of the pathogenic MC-1 and attenuated VIROG-43M strains revealed six mutations including two silent mutations located in the replicase and MP genes and four missense mutations in the replicase gene (Figure 1). Comparison of the nucleotide sequences of the pathogenic MC-2 and attenuated VIROG-43M strains revealed nine mutations in the replicase gene, six of which were silent and three were missense. It is interesting that these three missense mutations led to the same amino acid substitutions as those observed in the genome of the MC-1 strain (G-86 $\rightarrow$ S; S-534 $\rightarrow$ F; P-1362 $\rightarrow$ L). However, one MC-1-specific mutation leading to the P-698 $\rightarrow$ L substitution was absent from the MC-2 genome (Figure 1).

\subsection{Accumulation Dynamics of VIR0G-43M, MC-1 and MC-2 CGMMV Strains in Cucumber Plants}

For VIROG-43M, MC-1 and MC-2, the accumulation dynamics in plants was determined by DAS-ELISA. Cucumber plants were grown, inoculated and sampled as described in Materials and Methods. The results of the experiment are presented in Figure 2. It follows from these results that on the $3^{\text {rd }}$ d.p.i., the attenuated and pathogenic strains accumulated in plants in trace amounts, but even at this stage, the mean value for each strain already differed. From the $3^{\text {rd }}$ till the $7^{\text {th }}$ d.p.i., a significant increase in virion CP for all viral strains was detected; however, VIROG-43M accumulated in significantly less amounts than the pathogenic strains. The maximum rate of virus accumulation was observed from the $7^{\text {th }}$ till the $10^{\text {th }}$ d.p.i., when mean CP levels for all CGMMV strains reached a plateau. Moreover, on cucumber plants inoculated with the pathogenic strains, the first mosaic symptoms could be clearly observed. On the $14^{\text {th }}$ d.p.i., a little decrease in CP level was recorded for MC-1 and VIROG-43M strains, although this value increased for MC-2 strain. Thus, from the $3^{\text {rd }}$ till the $14^{\text {th }}$ d.p.i., the attenuated VIROG-43M accumulated in plants in significantly less amounts than the pathogenic strains; the level of pathogenic strain accumulation differed from the $3^{\text {rd }}$ till the $10^{\text {th }}$ d.p.i. and by the $14^{\text {th }}$ d.p.i., the difference between both pathogenic strains was insignificant.

\subsection{Worldwide Distribution of CGMMV Strains}

As mentioned above, CGMMV strains cause diseases in Cucurbitaceae plants in different countries. By analyzing NCBI GenBank data we retrieved 98 strains of CGMMV originated from 17 countries. The largest number of CGMMV strains (as great as 34) were described in China, next comes South Korea (13 isolates), followed by India (9 isolates) and Japan (7 isolates). In other countries less than 6 strains were characterized.

We performed phylogenetic analysis with all CGMMV strains retrieved from the NCBI GenBank. Note that 

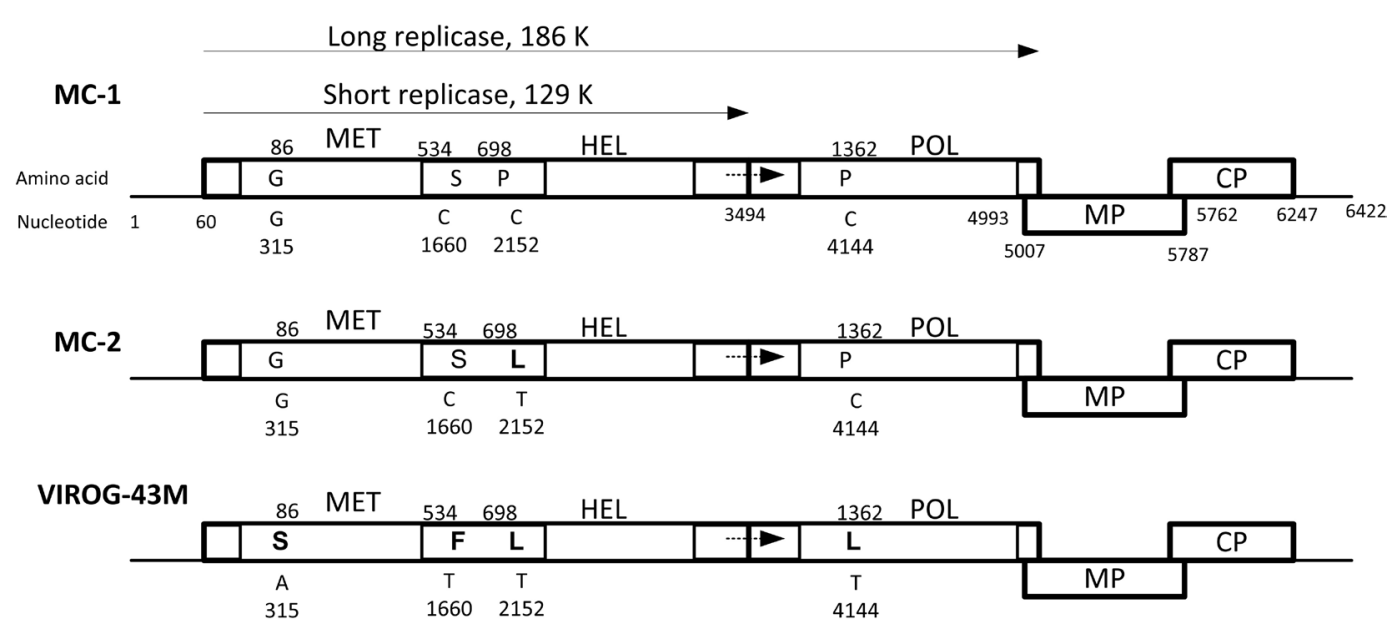

Figure 1. Schematic representation of the nucleotide mutations and amino acid substitutions found in the attenuated CGMMV strain VIROG-43M in comparison with pathogenic strains MC-1 and MC-2. The 5' and 3' UTRs are shown by single lines; the dotted arrow indicates the readthrough stop codon. The long and the short replicases, the movement protein (MP) and the coat protein (CP) are indicated with the bold bars. Three domains of replicases including MET—methyltransferase domain; HEL—helicase domain; POL_polymerase domain, are shown with regular bars.

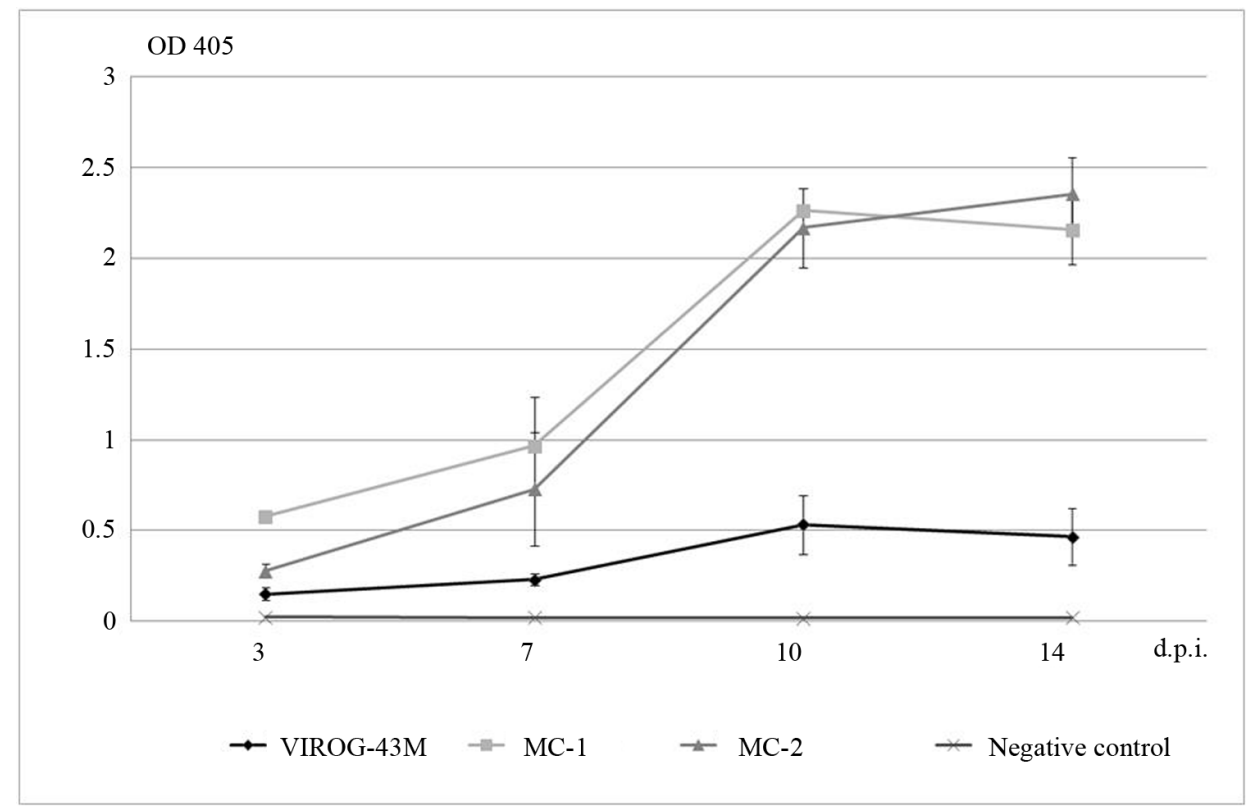

Figure 2. Accumulation dynamics of VIROG-43M, MC-1 and MC-2 strains in cucumber plants.

nucleotide sequences of the coat protein (CP) genes were used for phylogenetic tree construction since this particular gene was sequenced in most strains deposited to GenBank. Eighty-three of 98 CGMMV strains were taken for analysis. The remaining 15 strains either did not have the nucleotide sequence of the CP gene or the CP gene was not completely sequenced. The phylogenetic tree built using MEGA software [18] is shown in Figure 3. It is evident that all CGMMV strains group into two main clades: the small clade with 8 representatives including Moscow region, Russian strains (the clade is indicated with a bold line in Figure 3) and the large clade with the remaining 75 representatives. Some subclades of the large clade are entirely Asian groups including CGMMV isolates from China, Taiwan, Japan, South Korea and Indonesia (the clade is indicated by bold and light grey line in Figure 3). Other clades represent combined groups with Asian, European, Canadian and Australian CGMMV isolates. 


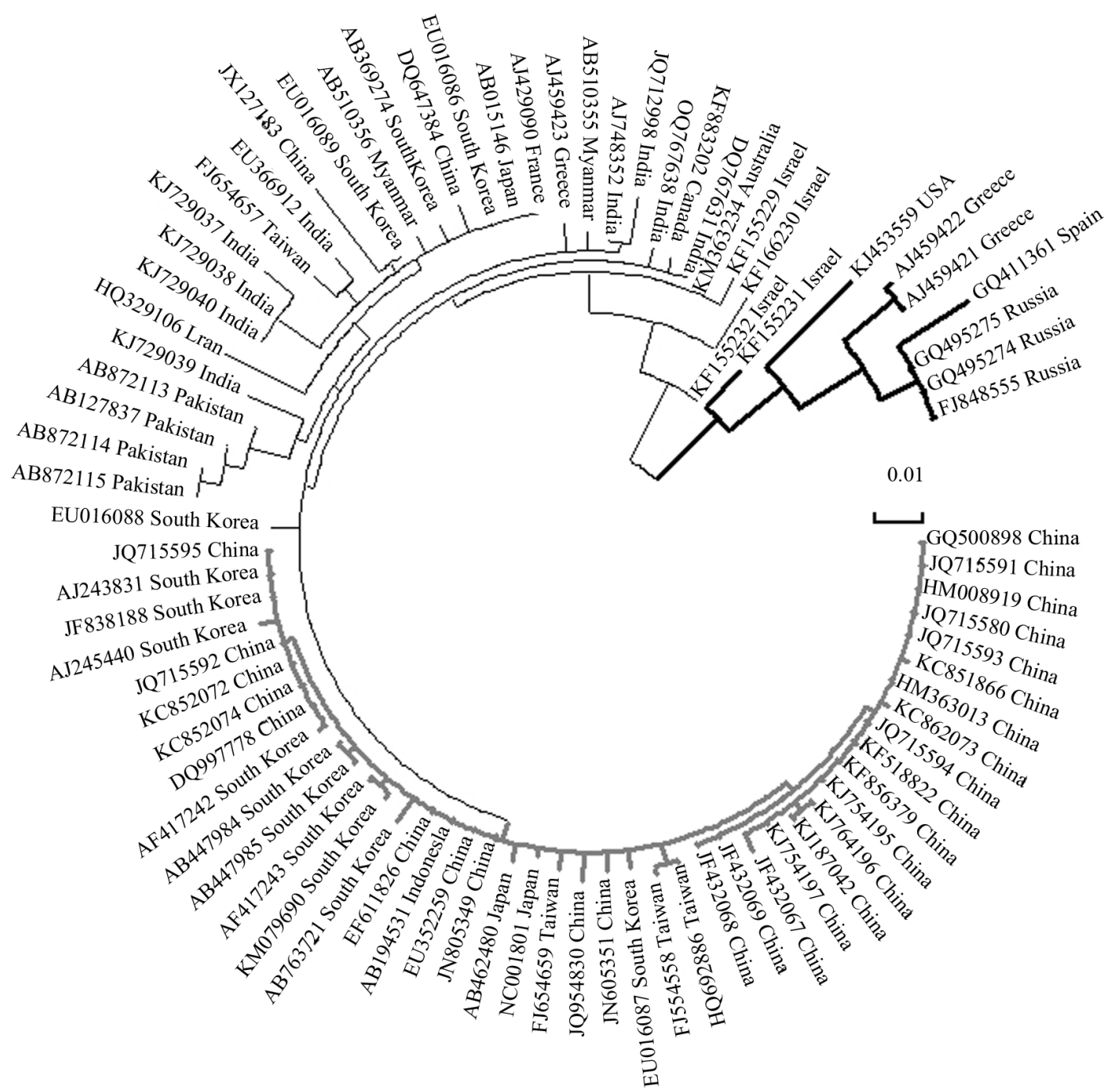

Figure 3. Molecular phylogenetic analysis of CGMMV strains by Maximum Likelihood method. The phylogenetic tree was built with MEGA software [18]. The tree is drawn to scale, with branch lengths measured in the number of substitutions per site; all positions with less than $95 \%$ site coverage were eliminated. CGMMV strains are specified with NCBI accession number and the country in which they were isolated. Main clades of the tree are shaded bold, black and light gray.

\section{Discussion}

CGMMV causes a severe disease of cucurbits that can lead to significant yield losses. Analysis of the largest available NCBI database revealed 98 strains of CGMMV originated from 17 different countries. From these data it follows that CGMMV is extensively studied in China and other Asian countries, while in European countries it remains poorly studied. Interestingly, this virus successfully invades novel areas: USA, Canada, and Australia were free of CGMMV infection, but in 2013-2014 the virus was discovered in these countries as well [20] [21]. In the Russian Federation, CGMMV often occurs in commercial greenhouses; however, the virus is poorly studied. We isolated and sequenced full-length genomes of two pathogenic strains from infected leaves of cucumber plants grown in greenhouses of the Moscow region. Using phylogenetic analysis with 83 full-length CP genes of CGMMV, we found that Russian strains together with isolates from Spain, Greece, USA and Israel form a very compact clade distinct from most CGMMV isolates. According to the phylogenetic tree (Figure 3), there were at least two sources of CGMMV infection. The first source gave rise to a small group of CGMMV strains that infected, among others, cucurbits in the Moscow region. The second source of infection most probably originated in Asian countries and Europe, and then spread to Australia. 
Besides the analysis of pathogenic CGMMV strains, we for the first time characterized the attenuated strain VIROG-43M that can be used for cucumber protection. In a number of trials conducted in laboratory and commercial greenhouses in diverse regions of Russian Federation on different cucumber varieties we clearly showed that VIROG-43M can be applied for cucumber protection, since this attenuated strain possesses high phenotypic stability and level of cross-protection against the pathogenic strain; furthermore, it contributes to significant yield gain. However, by the end of vegetation, a few plants treated with VIROG-43M developed disease symptoms possibly because of mutations. As the number of such plants was very low, and they appeared at late plant growing stage, they had no impact on yields. However, it would be interesting to characterize the genetic structure of these mutants, and it will be done in our future work.

Using the DAS-ELISA assay, we showed that VIROG-43M accumulated in cucumber plants in significantly less amounts than the pathogenic strains. Furthermore, we sequenced the genome of the attenuated VIROG-43M strain and compared it with pathogenic strains MC-1 and MC-2. We found three missense mutations that could be crucial for attenuation. Interestingly, that Kubota et al. (2003) reported that the mutation crucial for the attenuated phenotype of ToMV (L11A strain) is located in the intervening region between MET and HEL domains (IR), and IR should be considered crucial for the symptoms' attenuation [22]. Additional amino acid substitutions found in this particular region changed the severity of symptoms, but did not lead to their elimination [22]. Furthermore, in several mild tobamovirus strains, the mutations crucial for attenuation are located in this particular region of the viral genome. For example, the attenuated M strain of tobacco mosaic virus (TMV) has numerous mutations in comparison to the pathogenic U1 strain; however, the nucleotide substitutions at two specific positions located in IR led to the induction of U1-TMV-like symptoms [23]. Moreover, in the attenuated V-69 strain of ToMV, the only nucleotide mutation responsible for attenuation was also in IR, as it was shown by a reverse genetics approach [15]. Finally, the attenuated C-1421 strain of PMMoV had two nucleotide mutations in comparison to the parental pathogenic J strain, although only one located in IR led to the amino acid substitution and was responsible for attenuation [24]. Considering these findings, we may suggest that the attenuated VIROG- 43M strain most likely has the only substitution crucial for attenuation at position 534 located in IR, and substitutions of residues 86 and 1362 in the replicase protein probably influence the severity of symptoms.

According to current data, there are two mechanisms of cross-protection. The first one is based on inhibition of uncoating of a pathogenic strain in the presence of an attenuated strain [25]. The second mechanism involves posttranscriptional gene silencing (PTGS) induced in plants in response to attenuated virus inoculation. As a result, an incoming pathogenic strain is targeted by the PTGS-machinery, and the pathogenic RNA is degraded [26]. Kubota et al. showed that the ToMV short replicase protein, in addition to its main function, serves as a PTGS suppressor [22]. Moreover, the mutations crucial for attenuation and located in IR also led to defective PTGS suppressor activity, in other words, in symptomless plants the activity of the PTGS suppressor was lower or absent [22]. We suppose that cross-protection induced by VIROG-43M is also based on the PTGS mechanism, and the replicase protein of this strain acts as a suppressor with reduced activity.

\section{Acknowledgements}

The authors thank Elena V. Elisarova for assays of phenotypic stability and cross-protection and Dr. Andrew A. Shelenkov for useful suggestions in preparing the manuscript. This work was supported by RSF grant no. 16-16-00032. AAS is a recipient of the fellowship of the President of Russian Federation (MK-5568.2015.4).

\section{References}

[1] Moffett, P. (2009) Mechanisms of Recognition in Dominant R Gene Mediated Resistance. Advances in Virus Research, 75, 1-3. http://dx.doi.org/10.1016/S0065-3527(09)07501-0

[2] Nishiguchi, M. and Kobayashi, K. (2011) Attenuated Plant Viruses: Preventing Virus Diseases and Understanding the Molecular Mechanism. Journal of General Plant Pathology, 77, 221-229. http://dx.doi.org/10.1007/s10327-011-0318-x

[3] Ugaki, M., Tomiyama, M., Kakutani, T., Hidaka, S., Kiguchi, T., Nagata, R., Sato, T., Motoyoshi, F. and Nishiguchi, M. (1991) The Complete Nucleotide-Sequence of Cucumber Green Mottle Mosaic-Virus (Sh-Strain) Genomic Rna. Journal of General Virology, 72, 1487-1495. http://dx.doi.org/10.1099/0022-1317-72-7-1487

[4] Ainsworth, G.C. (1935) Mosaic Disease of Cucumber. Annals of Applied Biology, 22, 55-67. 
http://dx.doi.org/10.1111/j.1744-7348.1935.tb07708.x

[5] Varveri, C., Vassilakos, N. and Bem, F. (2002) Characterization and Detection of Cucumber Green Mottle Mosaic Virus in Greece. Phytoparasitica, 30, 493-501. http://dx.doi.org/10.1007/BF02979754

[6] Letschert, B., Adam, G., Lesemann, D., Willingmann, P. and Heinze, C. (2002) Detection and Differentiation of Serologically Cross-Reacting Tobamoviruses of Economical Importance by RT-PCR and RT-PCR-RFLP. Journal of Virological Methods, 106, 1-10. http://dx.doi.org/10.1016/S0166-0934(02)00135-0

[7] Slavokhotova, A.A., Andreeva, E.N., Shijan, A.N., Odintsova, T.I. and Pukhalskij, V.A. (2007) Specifics of the Coat Protein Gene in Russian Strains of the Cucumber Green Mottle Mosaic Virus. Russian Journal of Genetics, 43, 12211226. http://dx.doi.org/10.1134/S1022795407110038

[8] Vasudeva, R.S., Raychaudhuri, S.P. and Singh, J. (1949) A New Strain of Cucumis Virus 2. Indian Phytopathology, 2, 180-185.

[9] Liu, Y., Wang, Y.A., Wang, X.F. and Zhou, G.H. (2009) Molecular Characterization and Distribution of Cucumber Green Mottle Mosaic Virus in China. Journal of Phytopathology, 157, 393-399. http://dx.doi.org/10.1111/j.1439-0434.2008.01509.x

[10] Kim, S.M., Lee, J.M., Yim, K.O., Oh, M.H., Park, J.W. and Kim, K.H. (2003) Nucleotide Sequences of Two Korean Isolates of Cucumber Green Mottle Mosaic Virus. Molecules and Cells, 16, 407-412.

[11] Ali, A., Natsuaki, T. and Okuda, S. (2004) Identification and Molecular Characterization of Viruses Infecting Cucurbits in Pakistan. Journal of Phytopathology, 152, 677-682. http://dx.doi.org/10.1111/j.1439-0434.2004.00915.X

[12] Anonymous (2014) Cucumber Green Mottle Mosaic Virus. A Seed Production and Commercial Growers Guide. ASTA First-the seed.

[13] Nishiguchi, M., Kikuchi, S., Kiho, Y., Ohno, T., Meshi, T. and Okada, Y. (1985) Molecular-Basis of Plant Viral Virulence-The Complete Nucleotide-Sequence of an Attenuated Strain of Tobacco Mosaic-Virus. Nucleic Acids Research, 13, 5585-5590. http://dx.doi.org/10.1093/nar/13.15.5585

[14] Yang, G., Qiu, B.S., Liu, X.G., Li, Y. and Wang, X.F. (2002) Nonsense Mutations of Replicase and Movement Protein Genes Contribute to the Attenuation of an Avirulent Tomato Mosaic Virus. Virus Research, 87, 119-128. http://dx.doi.org/10.1016/S0168-1702(02)00025-4

[15] Istomina, E.A., Snegireva, P.B. and Shiian, A.N. (2004) Construction of a Full-Length cDNA of Tobacco Mosaic Virus Strain V-69 Genome. Genetika, 40, 1637-1645. http://dx.doi.org/10.1007/s11177-005-0058-0

[16] Ichiki, T.U., Nagaoka, E.N., Hagiwara, K., Uchikawa, K., Tsuda, S. and Omura, T. (2005) Integration of Mutations Responsible for the Attenuated Phenotype of Pepper Mild Mottle Virus Strains Results in a Symptomless Cross-Protecting Strain. Archives of Virology, 150, 2009-20. http://dx.doi.org/10.1007/s00705-005-0551-8

[17] Tan, S.-H., Nishiguchi, M., Sakamoto, W., Ogura, Y., Murata, M., Ugaki, M., Tomiyama, M. and Motoyoshi, F. (1997) Molecular Analysis of the Genome of an Attenuated Strain of Cucumber Green Mottle Mosaic Virus. Annals of the Phytopathological Society of Japan, 63, 470-474. http://dx.doi.org/10.3186/jiphytopath.63.470

[18] Tamura, K., Stecher, G., Peterson, D., Filipski, A. and Kumar, S. (2013) MEGA6: Molecular Evolutionary Genetics Analysis Version 6.0. Molecular Biology and Evolution, 30, 2725-2729. http://dx.doi.org/10.1093/molbev/mst197

[19] Tamura, K. and Nei, M. (1993) Estimation of the Number of Nucleotide Substitutions in the Control Region of Mitochondrial-DNA in Humans and Chimpanzees. Molecular Biology and Evolution, 10, 512-526.

[20] Ling, K.-S. and Li, R. (2014) First Report of Cucumber Green Mottle Mosaic Virus Infecting Greenhouse Cucumber in Canada. Plant Disease Journal, 98, 701.

[21] Tian, T. and Posis, K. (2014) First Report of Cucumber Green Mottle Mosaic Virus on Melon in the United States. Plant Disease Journal, 98, 1163. http://dx.doi.org/10.1094/PDIS-02-14-0176-PDN

[22] Kubota, K., Tsuda, S., Tamai, A. and Meshi, T. (2003) Tomato Mosaic Virus Replication Protein Suppresses VirusTargeted Posttranscriptional Gene Silencing. Journal of Virology, 77, 11016-11026. http://dx.doi.org/10.1128/JVI.77.20.11016-11026.2003

[23] Shintaku, M.H., Carter, S.A., Bao, Y. and Nelson, R.S. (1996) Mapping Nucleotides in the 126-kDa Protein Gene That Control the Differential Symptoms Induced by Two Strains of Tobacco Mosiac Virus. Virology, 221, 218-225. http://dx.doi.org/10.1006/viro.1996.0368

[24] Hagiwara, K., Ichiki, T.U., Ogawa, Y., Omura, T. and Tsuda, S. (2002) A Single Amino Acid Substitution in 126-kDa Protein of Pepper Mild Mottle Virus Associates with Symptom Attenuation in Pepper; The Complete Nucleotide Sequence of an Attenuated Strain, C-1421. Archives of Virology, 147, 833-840. http://dx.doi.org/10.1007/s007050200030

[25] Baulcombe, D.C. (1996) Mechanisms of Pathogen-Derived Resistance to Viruses in Transgenic Plants. Plant Cell, 8, 1833-1844. http://dx.doi.org/10.1105/tpc.8.10.1833

[26] Qu, F. and Morris, T.J. (2005) Suppressors of RNA Silencing Encoded by Plant Viruses and Their Role in Viral Infections. FEBS Letters, 579, 5958-5964. http://dx.doi.org/10.1016/j.febslet.2005.08.041 